\title{
Summer Elections 2013, as an Evaluative and Conditional Indicator Regarding Albania's EU Integration
}

\author{
$\mathrm{PhD} /$ Candidate, L.L.M. Erida Pejo
}

Lecturer, Faculty of Law, University of Tirana

\author{
Doi:10.5901/ajis.2013.v2n3p275
}

\begin{abstract}
The modern political history testifies unequivocally that the holding of free and fair elections is an important indicator, even one of the fundamental pillars of democracy, not only because they stand as way through which are legitimated fairly democratic and transparent people representatives, but political, legislative and institutional stability derives through them. The adaptation and proper approach towards best electoral practices of developed Western Europe democracies ensure and certifies their legitimacy. The Republic of Albania, pertaining not to oppose or move in a different dimension of such consensual agreement followed by the European countries as per the importance of democratic elections accomplishment, has already adopted enormous electoral reforms after the fall of communist regime, in order to ensure and guarantee "the rule of law" on European electoral heritage principles and their factual accomplishment. Such principles represent imperative conditions for countries which adhere towards the progressive consolidation of social and political democratization and at the same time "fight back" to become part of the modern European political family. Decision making structures of the European Union, regarding the countries with fragile or hybrid democracies like Albania, in the light of objectivity and meritocracy justify their standing regarding the verdict for grating or not the status of each candidate country for membership in the EU, on the basis of accomplishment and defining criteria's as imposed by them. So, in other words, optimal performance within western standards reflects the democratic character of the electoral performance, culture or political climate and the level of democracy in each respective country. June 2013 elections in Albania, for the reason of their key importance, constituted a very critical moment, because its future political destiny was dependant on the electoral performance definition and configuration. Such elections represented "the fire test" for the progress of negotiations and integration of the country in the European common structures and as such, they were under the judgment scale and supervision eye of the international opinion and also domestic one. The result of the whole electoral process testified that such elections were held in track with democratic standards, accomplishing international expectations, at the same time gaining Albanians faith and awakening the hope for a European future of their country.
\end{abstract}

\section{Introduction}

After quite an experience and long lasting isolation, where the state superstructure turned as a model of depriving rights and individual's freedoms by distanting them from world site and democratic governing, Albanians were firmly involved on building cut bridges in very un natyral ways of communication and culture with the rest of the continent to which they belong as an organic part, making them feel as an inherent part of the European continental civilization. The Albanian people and nation, throughout their secular existence has mutually benefited from the western civilizations, but in the 90s as they were eager to open and live through effective space on natural rights and freedoms as attributes of all mankind, as a result of shortages and vacumes lived through the lifeless abyss of communist regime, Albanians aimed to moderate a more extensive and intensive radius of interaction with European Civilization.

The Albanians devotion after uniqal abandonment of the exploiting totalitarian and slavery regime, in the early stages of political changes and their demand for the opening and guaranteeing the spaces towars a democratic state, seemed to be quite in sintony with the political strategies and platforms of the country innovative elites, but it took quite a long term of transition not easy in order to enjoy the "fruits or the oxygen" of the civilization, which has placed into the heart of political systems the philosophy of freedom, as a unique and universal value of all mankind and the power limitation, in other words has harmonized the interests of the civilian with those of the state.

In order to become part of the western model of democracy, which spirit has enlarged through a geometric progress, by means in all European countries, Albanians fairly perceived the need to adhere and connect in the quickest way to the existing European structures, this way abrogating de facto the autocratic models of governance, also by advancing with no compromise towards the prevailing European spirit known as the liberal democracy. As Heinz Galinski fairly argues, democracy can not be imposed to any society, nor it can be donated, neither it can be become a permanent 
piece of property. People should fight for it, as it should be protected every day. In the light of this monumental sentence, to the Albanian society as an immediate and necessary condition was the need to undertake adequate reforms for the "implementation" of democracy machine, where one of the fundamental pillars was the instituation of "free vote guarantee". Following the explanations of different lingual dictionaries or political and legal doctrines, democracy is defined as the people's governing and power belongs to people, such power can be exercised directly or through elected representatives, based on the free, direct and pluralist election system. ${ }^{1}$

In the beginning of the second century of its history as a free and independent state, Albanians are still aiming their efforts to build an efficient democracy, as a political and governing system. History indicates that, since antiquity up to present days of modernity, democracy has been presented with preminence, as the most rational way of governance, which legally guarantees fair rights on the binominal citizen - governing authority. Its essence derives above all from vote, from free elections. Having that in mind Abraham Lincoln stated that "democracy is at the service of the people and for the people".

The Albanian people have legally consecrated the instrument of vote as a foundation of democracy, in the act of its founding. At the third chapter of the Constitution, year 1998, in its Article 452, it is stipulated the right and guarantee of the free vote, for the exercise of which de iure Albanians waited for nearly 70 years. Elections held in 1923, for the Constitutional Assembly ${ }^{3}$, were considered as quasi within the standards set on that time. In the Albanian public opinion, such positive situation for strands of parliamentarism in the country, created ground for further optimism, but unfortunately in subsequent periods of the evolution and consolidation of the Albanian state, it did not met their expectations. This was the result as the following Democratic Revolution Government failed to hold parliamentary elections, due to the severe conditions in the interior political life of the country and international factors as well, which did not contribute to create an atmosphere favorable to the development of constitutional regime parliament.

The other stages of the history of parliamentarism in the Albanian state naturally, provide us with a detailed picture of its positive developments or failures, but it is precisely since 1992 when Albanians broke the depriving severity of the totalitarian regime which has been laied in many more than four decades and through the first political rotation, created the basis for establishing the most important institution in a parliamentary republic, parliament. ${ }^{4}$

Although, in 1992, Albanians completed the first and essential step of parliamentary democracy, the actual exercise of the right of the free voting, they failed to establish strong pillars for a liberal democracy. The implementation of multiple electoral reforms is one of the significant indicators during the political transition phase and energic efforts of all stakeholders to achieve the highest level of democratization of Albanian society.

In the wake of the second century of its history as a free and independent state, efforts are still made to effectively build an efficient democracy as a political and governing system. In the public domestic and international opinion as to the effectiveness of Albanian democracy a picture of delusions can be read, as a result of certain events taking place in the public political sphere. In many cases, elections and electoral law present a problematic relapse issue of democracy.

Albania, as one of the last countries in the former communist East Europe, which joined the process of democratization and the western model for democracy, along its political post - monist evolution, perhaps lacking the political maturity and social culture of electoral tradition, has applied many electoral systems. In the parliamentary elections of 31 March 1991 as the reference electoral model for Albanian politics served the majority pure system, which led the way in promoting peripheral competition between political parties and failed to accomplish the separation of

\footnotetext{
1 Seventeenth century marked the acceptance of analysis full of arguments in favor of democracy, as the center of which prevailed equal rights for all citizens. In 1776, the American colonies had the right to vote and in 1787 The Bill of Foundation legally sanctioned U.S. democracy. It assured de jure proportionally to the population, the representing of every state in the House of Representatives, as in federal elections, also presidential, of course excluding unfairly and in a discriminatory way Indians and slaves. In 1832, the British Royal Island extended the right to vote and only after about a century later sanctioned the right of the overall vote (1928).

2 The Constitution of the Republic of Albania, of 1998, Article 45/4 of it stipulates "The vote is personal, equal, free and secret."

${ }^{3}$ Electoral Law of 11 October 1923 defined a two stages voting system. 1923 elections ended December 27, after an innovative campaign, compared with the previous year's campaign in 1921, where experts apparently notified lack of well organized political parties and party with genuine character. The emergence of opposition was clear, even in a noisy way about the bitter debates that took place at the National Council on the report of the verification committee mandates and controversial discussions on the special committee to form the government.
}

4 See: Omari Luan, "Parliamentary System", Fourth Edition, Tirana 2004 
political systems. ${ }^{5}$

As a primary goal of the government that emerged from the 1991 elections, was the preparation of the country for the upcoming parliamentary elections, which were scheduled to be held in March 1992. For the accomplishment of elections implementation within the standards, preparation and adoption of legal framework was required. In accordance with the Law on Major Constitutional Provisions the law "On Political Parties" was adopted, which apparently was characterized by democratic principles of organization of political parties, but showed substantial deficiencies in its content.

Predefined elections of 1992, were conceived to develop according to a different electoral model, german model, in order to achieve the equality of votes with the creation of a stable parliamentary majority. The new electoral system aimed inter alia to avoid the crush of the parliament by different fractions, which would lead to a difficult establishment of a stable majority government. ${ }^{6}$

The Law on Major Constitutional Provisions sanctioned the creation of a legal mechanism to guarantee and protect the right to vote and the electoral administration within the democratic standards. To accomplish this goal and legal certification of elections to be held on March 22, 1992, the President of the Republic of Albania, based on the consensus of the main political parties of their respective proposals, decreed the creation of the Central Election Commission. The improvement of the electoral system in transitory countries and fragile democracy have proved and testified as a necessity in the performance for the implementation of the standards of modern democracy, guaranteeing the exercise of fundamental constitutional rights, also increasing the legitimacy and the accountability to all stakeholders in society. In order to consolidate the democratic system and its main pillars, among which a fundamental place is named under the "free elections", different electoral systems have been applied in Albania in order to reflect faithfully the citizens vote and real configuration towards the expression of political will in the parliament.

Analyzing the functioning of the adopted electoral systems in Albanian reality, certain different political effects and dinamics are identified. The pure majority system implemented on year 1991, which has generated political stability and progress in many consolidated western democratic countries differently, did not meet the goal and expectation to attain free and fair elections. The first pluralist elections in the country demonstrated in essence to be supervised and manipulated in favour of the party in power, bringing as a result a deformation on the free will of the voters, the lack of fair and equal competition for the opposition parties and a limited legitimacy of the elected parliament.

The mixed electoral system as applied in year 1992, brought ultimately to the separation of two political systems, aimed to unify the equity and fairness of the vote connected to the proportional system, with the need to create a more stable major representation assured such by the majority system. If elections held in year 1992, which produced the sole un contested elections by all political international and domestic factors in the country, reached to establish a political rotation of the power in peaceful conditions by setting a progress mark of the new albanian democracy, following elections in years 1997 and 2005, brought a political rotation of power characterizied by political tensions, electoral maneuvers and all sort of provoking political decisions. The lack of standards and enough democratic stability brought the need of implementation of the pure form of proportional system in 2009, with the aim of fulfilling contemporary European criterias. Through the current electoral system is intended that the political map of parliament be in a fair proportion to the political map of the country and simultaneously to ensure political stability, sustainable governance and institutional consolidation. Thus, between 1991-2009, Albania remained the only country in the Europe, which has experienced most or all existing voting systems, starting with the pure majority system, than mixed system or mixed propotional anding to the full proportional?.

\section{Election System as an Indicator of the Albanian Level of democracy}

The Albanian Society and its political stakeholders, in the centre of the motive of the constitutional amendments of 2008 and of the frequent changes to the electoral system, have evoked a rational argument, that the electoral law must reflect much more strongly the will of the citizens, in order to override the ethical problems surrounding the elections. The

\footnotetext{
${ }^{5}$ The first pluralist elections in 1991 produced 250 deputies, different political programs and served as the key on reestablishing diplomatic relations with the United States of America. Political programs with modern content or not, had no real weight in influencing and directing the will of the voters, for almost all sovereign was focused and pleased to change the political system.

${ }^{6}$ See: Omari Luan, "Parliamentary System", Fourth Edition, Tirana 2004, page 215.

7 See: Krasniqi Afrim, "Elections in Albania (1991-2008)", Tirana 2009.
} 
current electoral system, the proportional regional one who is considered controversial by some, has created a fragile political environment, the absence of consensus, polarization of society and political intolerance.

The European Union, as a sui generis organization focused on the promotion of parliamentary democracy, the rule of law and respect for human rights, seeks through its policies and practices to strengthen democracy and democratic institutions in the acceding countries, setting the above mentioned values as criteria for their integration into the community of European states. The construction of a functional democracy, already a strong aspiration of the Albanian society, requires overcoming many challenges including organising free elections. This is a process that constitutes a prerequisite for the establishment of a democratic society and is one of the primary requirements of the decisionmaking bodies of the European Union. While, not free and fair elections, that do not comply with international standards and the criteria set in the Code of good practices in Election Issues ${ }^{8}$, adopted by the Venice Commission's (European Commission for Democracy Through Law) in 2002, or with other acts of international law ${ }^{9}$, result in the creation of illegitimate and corrupt public institutions.

An electoral system is judged by the results it produces. In countries where governments are legitimized by free and fair elections, there is little space for the government to undertake un-democratic initiatives. Every electoral system should be transparent, practical and offer stability. Key questions that derive from the application of an electoral system are: how real is the proportionality of turning votes into representative seats? Have the elections produced stability and political consensus? Have they improved participation in politics?

In any democratic system, the electoral law is the main axis around which the political system is constructed and the competition between different forces of the country for representation and governance is regulated. Elections are the foundation stones and main indicator of the dominance of truth and democracy. The voting system determines the modalities of participation for all citizens in the democratic life and the authority of the electoral body for the formation of legislative, executive and leadership. Without this constitutional and institutional constituent, it is not possible to speak about a parliamentary Republic and the normal legal order which recognizes and guarantees the rights of the individual, nor is it possible to develop a legislative process for the modernization of state and the re-enforcement of constitutional and democratic institutions.

The Resolution 2000/47 of the General Assembly of the United Nations on "Promotion and consolidation of democracy", states the objectives that states should achieve: the consolidation of democracy through the promotion of pluralism, protection of human rights; maximizing the participation of individuals in decision-making and the development of public institutions, including an independent and effective legislative, and promotion of an electoral system, which can guarantee free and fair elections.

By summing up all of these principles, it is clear to see that their aim is the establishment and consolidation of a society with democratic culture. But, does the Albanian Society and its political class reflect this democratic culture? The United Nations Resolution shows that democratic societies are politically organised with a common consent to chose or adopt an electorals system that does not intend to promote pasivity but which aims to involve its citizens in creating a rational system of leadership and administration, in other words a modern goverment which has as its mission the

\footnotetext{
${ }^{8}$ Besides human rights and the Rule of Law, democracy is one of the three pillars of the European constitutional heritage, and the Council of Europe. Democracy is inconceivable if the elections are not conducted in accordance with certain principles that guarantee their democratic being. These principles represent a particular aspect of European constitutional heritage, which can be summarized in a logical way under the term "European electoral heritage". This legacy includes two aspects: first, constitutional principles of election rights, like voting as a universal, equal, free, secret and direct, and, second, the principle that elections can be truly democratic only if certain basic conditions of a democratic state based on the Rule of Law, like fundamental rights, sustainability of election rights and effective procedural guarantees.

9 The core of the European electoral heritage consists by all the international provisions. In an universal outline it is Article 25 of the International Covention for Civil and Political Rights, which expressly provides for all these principles, with the exception of direct voting, even though it meant the contents of Article 21 of the Universal Declaration of Human Rights General Assembly of the United Nations, 1948. At the European level it is Article 3 of the Adendum Protocol to the European Convention on Human Rights, which expressly stipulates the right to periodically elections through free and secret voting, as other principles constitute un understandable consequence of human rights court decisions. Regarding the principle of universality, see eg. The European Court of Human Rights No. 9267/81, decision on the matter Mathieu - Mohin and Clerfayt v. Belgium, 2 March 1987, Series A vol. 113, p. 23; decision issued Gitonas and Others v. Greece, 1 July 1997, no. 18747/91, 19376/92, 19379/92, 28208/95 and 27755/95, Collection of Decisions, 1997-IV, p. 1233, regarding the principle of equality, see eg. The above mentioned decision of Mathieu-Mohin and Clerfayt p. 23 The right to direct elections is also confirmed by the Court, at least indirectly, in Decision no. 24833/94 in the Matthews case against England, 18 February 1999 Summary of Decisions 1999-I, prg. 64.
} 
creation of a well-functioning state based on the rule of law, and the social stability.

Thus, a vital and inherent component for democracy is the free and democratic vote. The electoral system, an essential element in the institutional configuration that is implemented in a country, should not contain or show profound shortcomings or abnormalities that compromise the performance of the state and the quality of democracy.

In 2008 the Assembly of the Republic of Albania, due to the deviation of votes and legal gaps identified in the previous electoral law, made constitutional amendments (Article 64$)^{10}$ by replacing the mixed electoral system with the regional proportional system that is based on the division of different regions. The main reason for this was to correct previous distortions of the regional representations in order that the political map of the parliament could correspond with the country's political map. So that, the final result of the elections could represent with more truthfulness the real proportions of the votes won and the corresponding seats in the parliament.

Regardless of these changes, and the wide range of comments and opinions of politicians and the representatives of the civil society, the election system did not fulfill its intended purpose. The electoral law of 2008 did not bring about democratic election in Albania in accordance with the levels of other European countries. There were numerous weak evaluations, as well as internal and international factors that affected these elections. The post-election situation in 2009 was difficult to say the least, and local elections in 2011 were characterized by a tense atmosphere, creating the perception of irregularities, of political and institutional instability that constituted deviations from modern standards of democracy. These problems affected not only the electoral subjects, but also the legal bodies. The winners of the elections of 2009 were determined by panels of the electoral college, thus spreading a culture of immunity for the subjects that violate the law or distort the expressed will of the citizens. This situation, which was not in line with the directives of international forums, highlighted once again the weaknesses of the dominant governing culture. It pointed out the strong contrast with countries with advanced levels of democracy, who in similar situations have shown that the recognition of elections outcomes requires objective assessments from all competing sides. That, the right to govern is not about personal wars, but about the responsibility given to politicians by the majority of the citizens.

If we make a comparative analysis of the two models, comparing the presidential elections in the United States of America between candidates George Washington Bush and Albert Arnold Gore and the 2011 elections in Albania, we note a huge gab between the belief of the candidates and the parties they represent and the final judicial decisions. The lack of willingness of the political leaders of Albania to accept the results of these elections weakened the voters confidence and created a culture of suspicion, an atmosphere of uncertainty and cast many doubts on the judicial system of the country.

The U.S. Ambassador Mr. Alexander Arvizu, in one of his public pronouncements on the problematic nature of the 2011 elections in Albania, criticized key figures in Albanian politics and asked them to behave like their counterparts in countries that are models of democracy. He illustrated this with the case of the presidential candidate Al Gore who in 2000 accepted calmly and quietly the decision of the Federal Supreme Court of the United States of America, although he knew the Democrat's claims about irregularities in the vote counting processes, etc.

One of the consequences of these atypical situations for democratic societies, is that in the Freedom House report for the level of democracy in a developing country for the year 2012, Albania was included in the list of the partially democratic countries or countries with hybrid democracy. ${ }^{11}$ Although the same election systems ${ }^{12}$ have produced political

\footnotetext{
10 The Constitution of the Republic of Albania, 1998, in Article 64/1 stipulated: "The Assembly consists of 140 deputies". After the constitutional changes of 2008, the Constitution of the Republic of Albania its Article 64 changed as following: "The Assembly consists of 140 deputies, choosen by the system of proportional electoral multi-name districts. Such electoral districts have to comply with the administrative divisions at the organization level of administrative territory. The criteria and rules for the implementation of the proportional electoral system, election for zoning and for the number of seats for each area is provided in the Elections Code"

${ }^{11}$ According to Freedom House, Albania has suffered crashes in ranking regarding the electoral process. A major effect has been the lack of consensus among the main political forces for reform, paralyzing in continuity the progress towards Euro-Atlantic integration as the only option for real democratization of the country.

${ }_{12}$ British electoral system is a pure majoritarian system. This electoral system has contributed significantly in convincing consolidation of democracy, namely that majority. In British parliamentary monarchy, the application of this system has enabled the formation of a bipartisan political scene and the system has steadily produced stable parliamentary majority, without disregarding the establishment of authoritarian oppositions. Political parties which aimed at governing the country have to focus and win more than half of the electoral units, which have a total of 659 electoral units. The main British parties, which compete to win a majority of MPs in the House of Commons with the aim of selecting government, are the Labour Party and Conservative. British influence has naturally led to most other countries to adopt this system, which in our country could not create political stability. In 1949, Germany sanctioned the mixed proportional electoral system. This system still remains functional and has created a parliamentary regime with a democratic character,
} 
and institutional stability in other countries, it appears that no electoral system implemented in Albania has fulfilled the expectations of international bodies. By June 2013, all election systems implemented in Albania have failed to address the complex challenges of Albanian elections or to bring about positive changes.

Disturbances associated with the implementations of electoral systems, which have not provided fair conditions for all sides, have lead to strong requests from Brussels for solving the acute problems gripping Albanian politics. In their recommendations they insist that the electoral law should not become a tool for political manipulations, but like in other modern and liberal democracies it must function as a legal instrument that can guarantee free and fair elections. In order to obtain the status as a candidate country for EU membership, in 2012 Albania was asked in an imperative and categoric manner, to fulfill in an unconditional way the requirements articulated in Progress - Report of the European Commission ${ }^{13}$, where significant priority is given to the evidence of the realization of free and fair elections that express the interests of the majority.

When faced with this imperative and the internal pressures for integration into the European Union and the Western political culture, the political consciousness of the Albanian governing authorities reflected willingness and undertook constructive actions to achieve political consensus and to turn into reality the dream for creating a liberal and modern democracy in Albania.

The citizens and the political class of Albania, with their performance in the June 23 elections in 2013, demonstrated maturity in democratic culture, thus meeting the identified standards for free elections. The political parties and their leaders focused on the Europeanization of the country, integrated in their political platforms not only the binding directives set out by the decision-making bodies of the EU, but also one of the monumental statements of Abraham Lincoln - "democracy is regulated with more democracy".

The fulfillment of the conditions from the Copenhagen criteria stipulated in the declaration of the European Council of 1993, showed that organizing, maintaining and administering fair elections, can increase awareness and raise the public reason. Local opinion, the eve and after the 2013 election showed admirable intolerance towards political stubbornness, contributing towards the creation of a democratic election atmosphere. Elections like never before were seen as a guarantee for stability and as an effective tool for reshaping the democratic physiognomy of the Albanian society in general. Citizens themselves understood that elections that conform with European standards, can be a civilizing force not just a prima facie that was required as a categorical imperative for becoming a EU candidate. The construction of a right architectural dimension of progressive democratic politics should not be referred to the European concept of democracy and democratic principles of the rule of law.

International monitoring organizations and political exponents aspiring for a modern Albanian state, pinned their hopes on the solidarity of citizens and their critical consciousness. As a reference point, they were servicing a reasoning strategy that reflects the exercise of the right of active participation in politics and in the creation of a culture of political freedom, and above all in the consolidation of the rule of law in a democratic way. The modernization of public awareness, as complementary to the democratization process of the Albanian society was not only seen in the peaceful and legitimate contribution of the citizens in the electoral process, but also in the political arena. Often, despite holding opposing beliefs, competing entities respected each other as equal members of a democratic political community. Of

becoming a consolidated model for other western democracies. Through this election model, German citizens vote for a candidate at local elections and a vote for another favorite party may be given the federal level. So, in Germany, voter expresses his active will through the participance right, with two votes. Meanwhile, other seats remained vacant are passed towards closed lists of political parties. Unlike the above two states, other European countries have adopted different electoral systems in order to avoid parliamentary or governmental crises and create a sustainable legislatures in accordance with the interests or the general benefit of each respective country.

${ }^{13}$ EU Ambassador in Tirana, Ettore Sequi, while handling the progress - report for Albania in 2012, showed a special care to emphasize carefully that the final integration remains far and that many regarding European future for our country will depend on the elections of 2013. "Albania should improve the Rule of Law in order to start the membership negotiations. The elections of 2013, will play a crucial role for the integration of the country" he was quoted to has said. The European Commissioner for Enlargement and the Good Neighborhood Stephan Fule said that: "We will respect any choice that Albanians shall make. I hope that the politicians shall respect the results of the parliamentary elections. Political parties in government or not, should contribute in order that future elections meet a high level of democracy, living no space for contests". The head of delegation in the European Parliament for the Balkans, Eduard Kukan, has stated that: "Albania should be designed to use all opportunities in the integration process, so as to build a modern democratic system, which usually falls within services provided to Albanian citizens. Inter alia, he has required the construction of strong democratic institutions, efficient and functional, emphasizing the importance of the spirit that has rule of cooperation among all political forces and civil society, as prior and after the electoral process". 
course, in the context of Albanian political realities, these stances of rational and democratic behaviour constitute a massive breakthrough in political communication activities.

The result of the 2013 summer elections and their immediate acceptance by all parties showed to the local and international decision makers that the Albanian people and politicians are able to take conclusive actions out of respect for the law. The performing positions of the Albanian political parties (both the winners and losers) were on the border of modern European politics, by explicitly providing an innovative approach to the Albanian reality and by practicing western style communications. The presence of a state of law, amongst other things, shows that elections and electoral process should find the approval of all citizens. To sum up, if the 2013 summer elections are an important indicator of the conditional evaluation and integration of Albania into the EU, then it can be said with certainty that they give the stamp of validity to free and fair elections and that they are sure steps towards the consolidation of the institution of a free vote in Albania.

\section{References}

Anastasi Aurela, "Political Institutions and Constitutional Law in Albania (1912-1939)", Tiranë 1998.

Omari Luan, Anastasi Aurela, "The Constitutional Law", Tiranë 2008.

Krasniqi Afrim, "The Elections in Albania (1991-2008), Tiranë 2009.

Omari Luan, "Parliamentary System", Fourth Edition, Tiranë 2004.

Zaganjori Xhezair, "Democracy and the Rule of Law", Tiranë 2002.

Azzariti Gaetano, "Forme e soggetti della democrazia pluralista", Torino 2000.

Fisichella Domenico, "Elezioni e democrazia, un analisi comparata", II mulino saggi, 2008.

Pasquino Gianfranco, "I sistemi elettorali", II mulino intraduzioni, 2006.

\section{Legal Acts}

Constitution of the Republic of Albania, approved by Law No.8416, dated 21 October 1998, amended;.

Electoral Code of the Republic of Albania, approved by Law No.10019, dated 29 December 2008, amended;

The Code of Good Practice in Electoral Issues, approved by the European Commission for Democracy through Law, year 2002; International Convention on Civil and Political Rights;

Universal Declaration on Human Rights, General Assembly of the United Nations 1948;

European Convention on Human Rights, Addendum Protocol, 1995;

Decisions of European Court for Human Rights, Strasbourg.

\section{Reports}

Resolution No.2000/47 of the General Assembly of United Nations regarding "Promotion and Consolidation of Democracy"; Freedom House Report regarding the level of democracy in developing countries, for year 2012;

European Commission Progress Report for Albania, year 2012. 
